\title{
Gonadotrophin and progesterone concentrations in placentae of grey seals (Halichoerus grypus)
}

\author{
B. M. Hobson and I. L. Boyd* $\dagger$ \\ Reproductive Endocrinology Laboratory, Department of Obstetrics \& Gynaecology, 37 Chalmers \\ Street, Edinburgh EH3 $9 E W$, and ${ }^{*} N E R C$, Sea Mammal Research Unit, clo British Antarctic \\ Survey, Madingley Road, Cambridge CB3 OET, U.K.
}

\begin{abstract}
Summary. Chorionic gonadotrophin (CG) measured by bioassay and progesterone by immunoassay were present in the placentae of grey seals (Halichoerus grypus) from about 20 days after implantation until parturition. During this period a small and significant decrease in the concentration and a large increase in the total amount of placental CG occurred. The biological activity of seal placental CG was neutralized with an anti-hCG serum. There was a correlation between fetal length and the total amount of progesterone in the placenta. The corpus luteum persisted throughout pregnancy and there was a significant correlation $(P<0.001)$ between CL diameter and the weight of the ipsilateral ovary. Hypertrophy of fetal testes and ovaries was observed and adult gonad size was reached at about the time of parturition. We suggest that placental $\mathrm{CG}$ is the hormone responsible for the precocious enlargement of fetal gonads in grey seals.
\end{abstract}

\section{Introduction}

British colonies of grey seals (Halichoerus grypus) produce most of their pups between September and December. Gestation, which includes a period of 'delayed implantation' or 'suspended development' of about 150 days, lasts approximately 350 days (Hewer \& Backhouse, 1968). A single well developed pup is normally produced but twins have been recorded (Spotte, 1982). Oestrus and mating occur 14-18 days post partum.

Accounts of the reproductive biology of seals have concentrated upon the measurement and morphology of fetal and maternal reproductive organs (Harrison, 1951, 1960, 1963; Harrison, Matthews \& Roberts, 1952; Laws, 1956; Amoroso et al., 1965; Harrison \& Young, 1966; Sinha \& Erickson, 1972; Bigg \& Fisher, 1974; Boshier, 1977, 1981; Sinha, Erickson \& Seal, 1977). There are few reports on the estimation of reproductive hormones in pinnipeds (Daniel, 1974, 1975; Griffiths, Seamark \& Bryden, 1979; Liggins, France, Knox \& Zapol, 1979; Raeside \& Ronald, 1981; Boyd, 1983). Recently, concern about the effect of organic marine pollutants on reproduction in seals (Helle, Olsson \& Jensen, 1976; Reijnders, 1980, 1982; Helle, 1981) has necessitated further studies of seals to determine normal levels of reproductive hormones. Harrison \& Young (1966) described the structure of the grey seal placenta and found some evidence of secretory activity in the syncytial trophoblast.

In this study placental chorionic gonadotrophin (CG) and placental progesterone concentrations have been estimated during pregnancy in grey seals. The concentration of these hormones has been related to length of gestation, fetal sex and size, and to the weight of gonads and placenta.

† Present address: Institute of Terrestrial Ecology, Monks Wood Experimental Station, Abbots Ripton, Huntingdon, Cambs PE17 2LS, U.K. 


\section{Materials and Methods}

Thirty-six (36) pregnant grey seals were shot at the Farne Islands between May and October, 1981. The mean \pm s.e.m. age of these animals, determined by the method of Hewer (1960), was $23.9 \pm$ 1.5 years with the youngest estimated to be 9 and the oldest 47 years. The carcasses were dissected within $1 \mathrm{~h}$ of death. The maternal ovaries were removed, weighed individually and the diameter of the corpus luteum (CL) of pregnancy measured. All 36 females had a single fetus in utero ( 20 female, 16 male). The fetus, placenta and membranes were removed and weighed before being frozen at $-20^{\circ} \mathrm{C}$. The length, weight and sex of each fetus was noted and the gonads of most were weighed. The body and gonadal weights of 5 still-born pups, 2 male (P11, P18) and 3 females (P3, P53, P54), were recorded. These animals came from the Island of North Rona.

\section{Extraction and bioassay of placental gonadotrophin}

The frozen placentae were thawed, dissected free from umbilical cord and membranes, weighed and halved. For the assay of CG half of each placenta was homogenized in ice cold acetone and ice cold diethyl ether $(5: 1, \mathrm{v} / \mathrm{v}, 6 \mathrm{ml} / \mathrm{g})$. The homogenized tissue was kept at $+4^{\circ} \mathrm{C}$ overnight and collected by filtration on a Buchner funnel. This extraction method has been shown to remove steroids present in placental tissue of primates (Hobson, 1972). The dried acetone-ether material, before assay, was taken up in $0.9 \%(w / v) ~ N a C l$, left overnight at $+4^{\circ} \mathrm{C}$, centrifuged and the supernatant assayed.

The gonadotrophic activity of placental extracts and the hCG standard was assayed using the increase in uterine weight of immature female mice (Hobson, 1983). The method was essentially that of Levin \& Tyndale (1937) in which mice were injected subcutaneously with one third of the total dose on 3 consecutive days and killed $72 \mathrm{~h}$ after the first injection. Uteri, dissected free from mesentery, fat, ovaries and oviducts, were cut at the utero-cervical junction. Intrauterine fluid was expressed between filter paper before the uterus was weighed to the nearest $0.1 \mathrm{mg}$ on a torsion balance.

Five or 10 mice were used at each of 2 or 3 dose levels, a log dose interval of $0 \cdot 301$ of the unknown and hCG standard preparation being assayed simultaneously. Estimates of relative potency of the placental extracts were expressed per $\mathrm{g}$ wet weight as International Unit equivalents of the Second International Standard for hCG (i.u. hCG, WHO code 61/16). The smallest amount of hCG which produced a significant $(P<0.01)$ response in the bioassay, compared with that in salineinjected controls, was $0.625 \mathrm{i}$.u. The response parameter was the logarithm of the mouse uterine weight. The results and tests of validity of the bioassays in this investigation were calculated according to Gaddum (1953).

\section{Extraction and immunoassay of placental progesterone}

The other half of each placenta was used for the extraction of progesterone by a method used to extract the hormone from human plasma (Scaramuzzi, Corker, Young \& Baird, 1975). Placental tissue was homogenized in absolute ethanol at a concentration of $1 \mathrm{~g}$ tissue per $20 \mathrm{ml}$. Ethanol was removed under nitrogen at $40^{\circ} \mathrm{C}$ and $500 \mu \mathrm{l}$ equivalents of the extract were dissolved in $0.2 \mathrm{ml}$ petroleum ether (Analar reagent grade). The ether was removed by evaporation to dryness under nitrogen and the residue dissolved in $0.2 \mathrm{ml}$ phosphate buffer. Duplicate $0.1 \mathrm{ml}$ portions of the extract were assayed with the specific radioimmunoassay (RIA) using sheep anti-progesterone antiserum $91929 / 9$ as described by Scaramuzzi et al. (1975). There was little or no cross-reaction between this antiserum and androstenedione, cortisol, pregnenolone, testosterone, or 17 $\alpha$-hydroxyprogesterone. There was a significant cross-reaction with progesterone, $11 \alpha$ - and $11 \beta$-hydroxyprogesterone and 11-ketoprogesterone. 


\section{hCG antiserum}

The antiserum was a rabbit anti-hCG preparation raised against 'Gonadex' an hCG preparation (Leo, Sweden) having a biological activity of $5000 \mathrm{i} . \mathrm{u} . / \mathrm{mg}$. This antiserum was used to see whether it would neutralize the gonadotrophic activity of a seal placental extract. This and the hCG standard were assayed with and without the addition of antiserum. The amount of antiserum used was $15 \mu \mathrm{l}$ per total dose per mouse.

\section{Results}

\section{Maternal ovaries}

During pregnancy both ovaries of individual animals increased in weight (Table 1) and the ovary bearing the CL was significantly (paired-sample $t$ test, $P<0 \cdot 001$ ) heavier (mean \pm s.e.m. $14.3 \pm 0.69 \mathrm{~g}$ ) than the contralateral ovary (mean \pm s.e.m. $10 \cdot 6 \pm 0.42 \mathrm{~g}$ ). The CL also increased in size during pregnancy and there was a significant correlation $(r=0.70, P<0.001)$ between $\mathrm{CL}$ diameter and ovarian weight (Table 1). The regression of ovarian weight $(x)$ on CL diameter $(y)$ was $y=0.39+14 \cdot 1 x$.

\section{Fetal gonadal weight, body weight and length relationships}

Body weight and length were recorded for 16 male and 20 female fetuses (Table 1). There was a significant correlation between body weight and length $(r=0.91, P<0.001)$. Boyd (1984) has shown that the length of fetal grey seals was directly correlated, from the time of implantation, with the duration of gestation. Gonadal weight, placental weight and hormone estimations have been related to this measurement.

Paired fetal ovarian weights increased during pregnancy (Table 1). The still-born pups from North Rona had the heaviest ovaries (Table 1). The correlation between body length and paired ovarian weights was significant $(r=0.72, P<0.01)$. Similarly, paired testicular weights increased during pregnancy (Table 1). The relationship between paired testicular weights and body length was positively and significantly correlated $(r=0.62, P<0.0005)$. There was a significant correlation between fetal length and placental weight $(r=0.94, P<0.0001)$ (Table 1$)$.

\section{CG activity in placental extracts}

Table 1 shows the results obtained with the biological assay on the acetone-ether extracts of 36 grey seal placentae. No significant departure from parallelism or linearity was observed between log-dose and log-response of the placental extracts and the hCG standard. An index of precision $\lambda$ was calculated for each assay (Gaddum, 1931). The median value for $\lambda$ was 0.061 (range $0.035-$ $0 \cdot 10$ ). As pregnancy advanced there was a small but significant decrease in the concentration and a large increase in the total amount of CG in placentae. Correlations between fetal length, i.u. $\mathrm{CG} / \mathrm{g}$ and i.u. CG/placenta were $r=-0.337(P<0.05)$ and $r=+0.610(P<0.001)$ respectively (Table 1; Text-fig. 1a).

\section{Neutralization of placental CG activity}

The biological activity of a seal placental extract and the hCG standard was suppressed by the anti-hCG serum (Table 2). The mean uterine weights of mice injected with hCG only were significantly $(P<0.001)$ greater at all 3 dose levels than those of the saline-injected controls and those mice injected with hCG plus antiserum. The mean uterine weights of mice injected with an extract of seal placenta (No. 2229) were, at all 3 dose levels, significantly $(P<0.0001)$ heavier than 


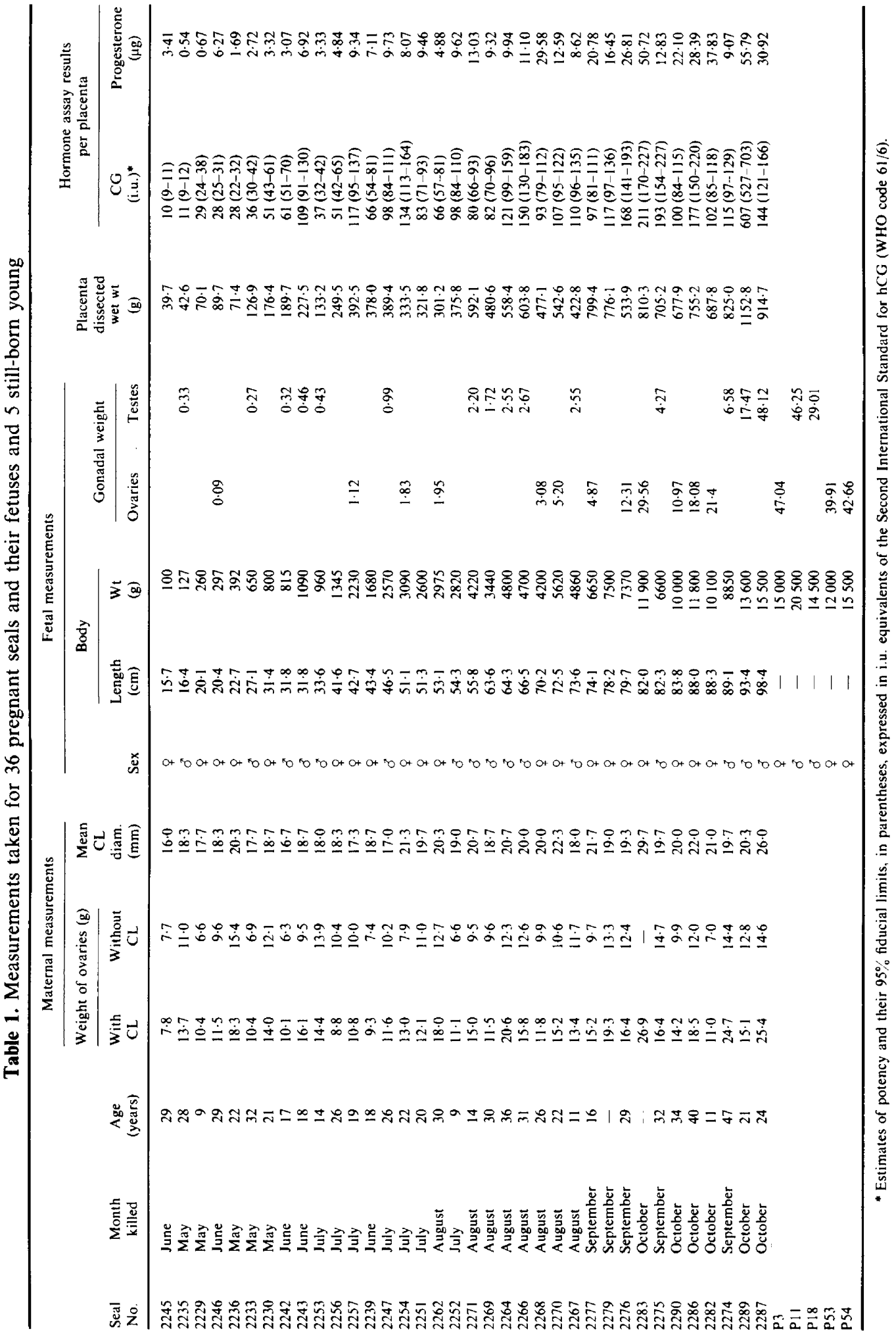




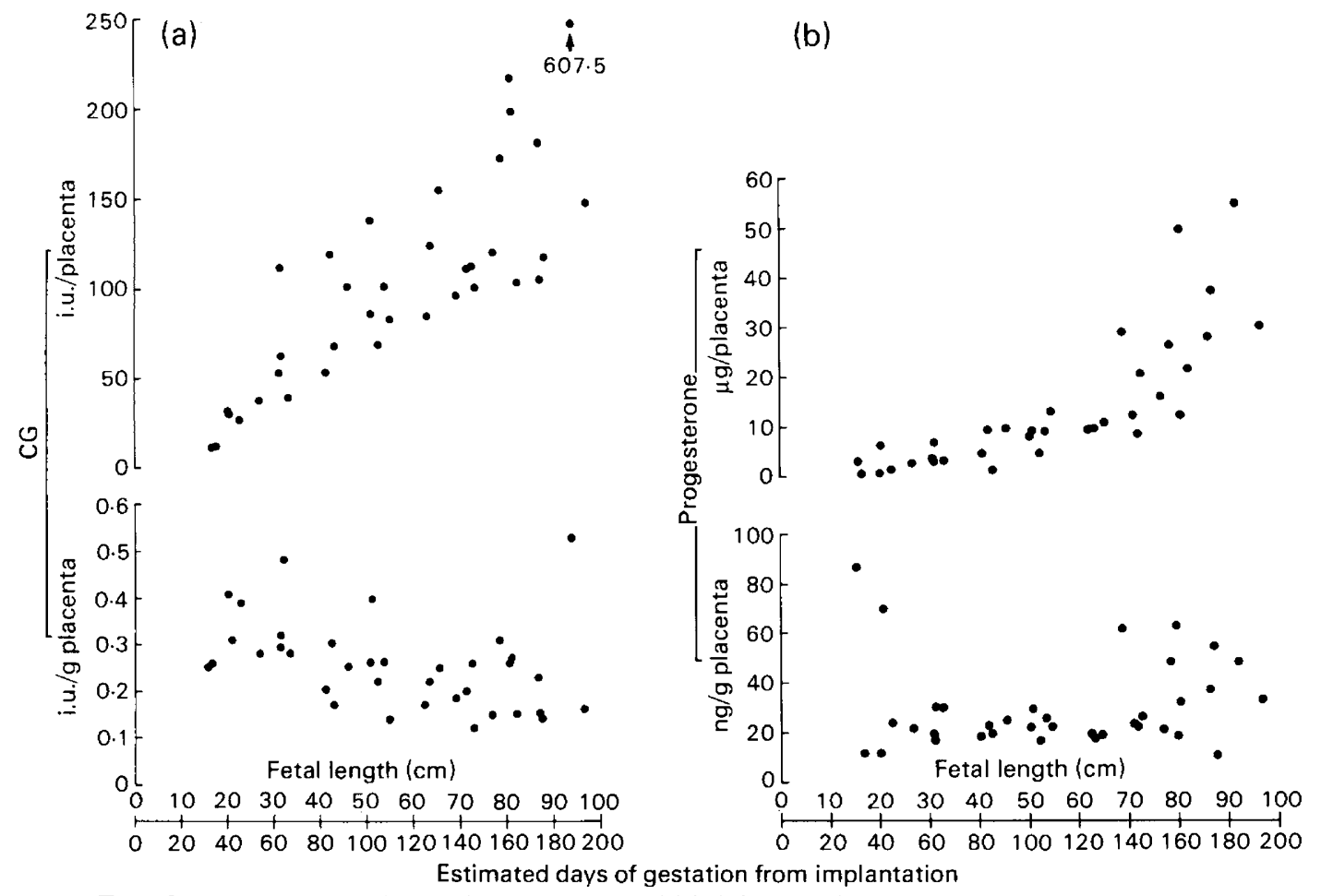

Text-fig. 1. Concentration and total amount of (a) CG and (b) progesterone in the placentae of 36 grey seals in relation to fetal length and estimated gestation. Linear regression of total placental CG and total placental progesterone on fetal length was $y=40 \cdot 1+0 \cdot 153 x$ and $y=37 \cdot 3$ $+1.42 x$ respectively.

Table 2. Neutralization with an anti-hCG serum of the biological activity of a seal placental extract and the hCG preparation

\begin{tabular}{cccc}
\hline & & \multicolumn{2}{c}{ Mean \pm s.e.m. uterine wt (mg) } \\
\cline { 3 - 4 } Material & Dose & With antiserum & Without antiserum \\
\hline Seal placenta & $28 \mathrm{mg}$ & $7.04 \pm 0.11$ & $11 \cdot 6 \pm 0.48$ \\
(No. 2229) & $56 \mathrm{mg}$ & $7.48 \pm 0.24$ & $21 \cdot 2 \pm 1 \cdot 22$ \\
& $112 \mathrm{mg}$ & $8.64 \pm 0.41$ & $41.3 \pm 3.48$ \\
hCG standard & $0.125 \mathrm{i.u}$. & $7.3 \pm 0.85$ & $12.2 \pm 0.46$ \\
& $0.25 \mathrm{i} . \mathrm{u}$. & $7.6 \pm 0.52$ & $24.7 \pm 1.82$ \\
Saline control & $0.50 \mathrm{i.u}$. & $7.7 \pm 0.16$ & $54.9 \pm 3.29$ \\
& $3.0 \mathrm{ml}$ & & $6.9 \pm 0.35$ \\
\hline
\end{tabular}

$* n=5$ except for saline control for which $n=10$.

those of mice injected with placental extract plus antiserum. The response of mice injected with the placental extract plus antiserum was not, with the exception of the top dose, significantly $(P>$ $0 \cdot 20$ ) greater than that of mice injected with saline.

\section{Progesterone}

There was considerable individual variation in the concentration of placental progesterone ranging from 9.6 to $86 \mathrm{ng} / \mathrm{g}$ with a mean \pm s.e.m. of $29.8 \pm 2.96(n=36)$. No correlation was found 
between fetal length and steroid concentration $(r=0.086, P>0.05)$ but there was a significant correlation $(r=0.752, P<0.0001)$ between total placental progesterone and fetal length (Text-fig. 1b). There was a positive and significant correlation $(r=0.66, P<0.0001)$ between total placental progesterone and CL diameter but no significant relationship $(P>0.2)$ between progesterone concentration and $\mathrm{CL}$ diameter.

\section{Discussion}

In the grey seal the CL increased in size throughout pregnancy. Whether this increase in size reflected a continuing contribution to the steroid pool has not been ascertained. I. L. Boyd (unpublished) found a significant $(P<0.0001)$ relationship between CL diameter and maternal plasma progesterone levels in the grey seal. Although the CL has an essential supportive role in early pregnancy it is not known whether it is necessary for the maintenance of progesterone levels in late pregnancy. Declining plasma progesterone concentrations and the subsequent involution of the CL coincide with parturition in the grey seal (Boyd, 1983). This investigation has shown that the total placental content of progesterone rises as pregnancy progresses, with maximum amounts occurring towards the end of pregnancy (Table 1; Text-fig. 1b). The values for the concentration of progesterone in placental tissue were variable and did not correlate with stage of gestation (Textfrg. 1b). A progesterone concentration of $24 \mu \mathrm{g} / \mathrm{kg}$ has been recorded from a term placenta of a common seal (Phoca vitulina) (Harrison, 1960). In women there is a progressive rise in progesterone to mean term values of $700 \mu \mathrm{g}$ per placenta and a steady decline in concentration of the hormone from peak levels at 2 months of gestation (Zander \& von Münstermann, 1956). These values are at least 10 times greater than those of the grey seal in spite of seals having a heavier placenta than women.

In early pregnancy in women, mice and guinea-pigs, gonadotrophin concentration in placental tissue reaches a peak before falling to lower levels (Hobson, 1972; Wide \& Wide, 1979; Humphreys, Hobson \& Wide, 1982). A well defined peak was not observed with the seal material in this investigation. The total amount of CG in the placenta of the grey seal increased significantly from about 170 days after conception, about 20 days after implantation, until the end of pregnancy. During the same period there was a small but significant decrease in the concentration of placental CG (Table 1; Text-fig. 1a). Although the term placenta of man and the great apes is much smaller than that of the seal the concentration and total amount of $\mathrm{CG}$ in the primate placenta is significantly higher. The concentration of CG in term placentae of women, chimpanzees and orang-utans is $2.9-42.4$ i.u./g $(\mathrm{N}=40), 12.4-33.6$ i.u./g $(\mathrm{N}=3)$ and $3.5-75.8 \mathrm{i} . \mathrm{u} . / \mathrm{g}(\mathrm{N}=3)$ respectively (Hobson \& Wide, 1974, 1981). In mammals which produce a placental gonadotrophin early in pregnancy a luteotrophic role can be assigned to it but later in pregnancy its actions are less certain. In seals, as in humans and horses, the structure and size of fetal gonads have all the appearances of stimulation in utero. The gonads of the fetal seal continue to grow until at term they equal or exceed in size the gonad of the mature adult (Table 1). After birth, the gonads of newborn seals regress and do not attain adult size until puberty at approximately 3 years of age. Amoroso, Harrison, Matthews \& Rowlands (1951) and Amoroso et al. (1965) speculated upon the nature of this stimulation and observed that the interstitial cells of grey seal gonads reacted in a manner resembling a response to pituitary luteinizing hormone. They concluded that unless it could be assumed that the placenta secreted a chorionic gonadotrophin the observed changes might be due to oestrogens or fetal pituitary gonadotrophin. The sub-unit structure of seal placental gonadotrophin has not been studied by chromatographic methods similar to those used for primate placentae (Hobson \& Wide, 1981), but it has been demonstrated that the biologically active gonadotrophin present in seal placental extracts can be neutralized by an anti-hCG serum. The results of the present investigation provide evidence for the presence of a placental CG which is most probably responsible for the gonadal hypertrophy of fetal grey seals. 
We thank the staff of the Sea Mammal Research unit for valuable help, especially John Prime and Dr J. Harwood, and Mrs J. Flockhart and Mr I. A. Swanston for technical assistance. This work was partly funded by the Natural Environment Research Council and Organon Teknika Ltd.

\section{References}

Amoroso, E.C., Harrison, R.J., Matthews, L.H. \& Rowlands, I.W. (1951) Reproductive organs of near term and new born seals. Nature, Lond. 168, 771-772.

Amoroso, E.C., Bourne, G.H., Harrison, R.J., Matthews, L.H., Rowlands, I.W. \& Sloper, J.C. (1965) Reproductive and endocrine organs of foetal, new born and adult seals. J. Zool., Lond. 147, 430-486.

Bigg, M.A. \& Fisher, H.D. (1974) The reproductive cycle of the female harbour seal off Southeastern Vancouver Island. In Functional Anatomy of Marine Animals, Vol. 2, pp. 329-347. Ed. R. J. Harrison. Academic Press, London.

Boshier, D.P. (1977) Observations on the corpus luteum of the grey seal (Halichoerus grypus) at the time of ova implantation. In Functional Anatomy of Marine Animals, Vol. 3, pp. 333-359. Ed. R. J. Harrison. Academic Press, London.

Boshier, D.P. (1981) Structural changes in the corpus luteum and endometrium of seals before implantation. J. Reprod. Fert., Suppl. 29, 143-149.

Boyd, I.L. (1983) Luteal regression, follicle growth and the concentration of some plasma steroids during lactation in grey seals (Halichoerus grypus). J. Reprod. Fert. 69, $157-164$.

Boyd, I.L. (1984) The relationship between body condition and the timing of implantation in pregnant grey seals (Halichoerus grypus). J. Zool., Lond. 203, $113-123$.

Daniel, J.C. (1974) Circulating levels of oestradiol-17ß during early pregnancy in the Alaskan fur seal showing an oestrogen surge preceding implantation. J. Reprod. Fert. 37, 425-428.

Daniel, J.C. (1975) Concentrations of circulating progesterone during early pregnancy in the northern fur seal, Callorhinus ursinus. J. Fish. Res. Bd Can. 21, 773-811.

Gaddum, J.H. (1931) The determination of vitamin A in cod-liver oils. Statistical examination of the results. Biochem. J. 25, 1113-1119.

Gaddum, J.H. (1953) Simplified mathematics for bioassays. J. Pharm. Pharmac. 5, 345-358.

Griffiths, D.J., Seamark, R.F. \& Bryden, M.M. (1979) Summer and winter cycles in plasma melatonin levels in the elephant seal (Mirounga leonina). Aust. J. biol. Sci. 32, 581-586.

Harrison, R.J. (1951) Changes in the reproductive tract of foetal and adult seals. $J$. Anat. 85, 428.

Harrison, R.J. (1960) Reproduction and reproductive organs in common seals (Phoca vitulina) in the Wash, East Anglia. Mammalia 24, 372-385.

Harrison, R.J. (1963) A comparison of factors involved in delayed implantation in badgers and seals in Great Britain. In Delayed Implantation, pp. 99-114. Ed. A. C. Enders. University Chicago Press, Chicago.

Harrison, R.J. \& Young, B.A. (1966) Functional characteristics of the pinniped placenta. Symp. zool. Soc. Lond. 15, 47-68.
Harrison, R.J., Matthews, L.H. \& Roberts, J.M. (1952) Reproduction in some pinnipedia. Trans. zool. Soc. Lond. 27, 437-531.

Helle, E. (1981) Reproductive trends and occurrence of organochlorines and heavy metals in the Baltic seal populations. International Council for the Exploration of the Sea. C.M. 1981/E; 37 (Mimeo).

Helle, E., Olsson, M. \& Jensen, S. (1976) DDT and PCB levels and reproduction in ringed seals from the Bothnian Bay. Ambio 5, 188-189.

Hewer, H.R. (1960) Age determination of seals. Nature, Lond. 187, 959-960.

Hewer, H.R. \& Backhouse, K.M. (1968) Embryology and foetal growth rate in the grey seal (Halichoerus grypus). J. Zool., Lond. 155, 507-533.

Hobson, B.M. (1972) Gonadotrophin concentrations in the placentae of man, rhesus monkey and the marmoset. Folia primat. 18, 35-40.

Hobson, B.M. (1983) An appraisal of the mouse uterine weight assay for the bioassay of chorionic gonadotrophin in the macaque term placenta. J. Reprod. Fert. 68, 457-463.

Hobson, B.M. \& Wide, L. (1974) Chorionic gonadotrophin in the human placenta in relation to the sex of the foetus at term. $J$. Endocr. 60, 75-80.

Hobson, B.M. \& Wide, L. (1981) The similarity of chorionic gonadotrophin and its subunits in term placentae from man, apes, old and new world monkeys and a prosimian. Folia primat. 35, 51-64.

Humphreys, E.M., Hobson, B.M. \& Wide, L. (1982) Gonadotrophic activity of the guinea-pig placenta during pregnancy. J. Reprod. Fert. 65, 231-238.

Laws, R.M. (1956) The elephant seal (Mirounga leonina Linn). 3. The physiology of reproduction. Falk. Is. Dep. Serv. Sci. Rep. 15, 1-74.

Levin, L. \& Tyndale, H.H. (1937) The quantitative assay of "follicle-stimulating" substances. Endocrinology 21, 619-628.

Liggins, J.C., France, J.T., Knox, B.S. \& Zapol, W.M. (1979) High corticosteroid levels in plasma of adult and foetal Weddell Seals (Leptonychotes weddelli). Acta endocr., Copenh. 90, 718-726.

Raeside, J.I. \& Ronald, K. (1981) Plasma concentrations of oestrone, progesterone and corticosteroids during late pregnancy and after parturition in the harbour seal, Phoca vitulina. J. Reprod. Fert. 61, 135-139.

Reijnders, P.J.H. (1980) Organochlorine and heavy metal residues in harbour seals from the Wadden Sea and their possible effects on reproduction. Neth. J. Sea Res. 14, 30-65.

Reijnders, P.J.H. (1982) On the ecology of the harbour seal Phoca vitulina in the Wadden Sea: population dynamics, residue levels, and management. Vet. Quart. 4, 36-42.

Scaramuzzi, R.J., Corker, C.S., Young, G. \& Baird, D.T. (1975) Production of antisera to steroid hormones in sheep. In Steroid Immunoassay, pp. 111-122. Eds 
E. H. D. Cameron, S. G. Hillier \& K. Griffiths. Alpha Omega Publishing, Cardiff.

Sinha, A.A. \& Erickson, A.W. (1972) Ultrastructure of the corpus luteum of Antarctic seals during pregnancy. Z. Zellforsch. mikrosk. Anat. 117, 35-45.

Sinha, A.A., Erickson, A.W. \& Seal, U.S. (1977) Fine structure of the seminiferous tubules in antarctic seals. Cell Tiss. Res. 178, 183-188.

Spotte, S. (1982) The incidence of twins in pinnipeds. Can. J. Zool. 60, 2226-2232.
Wide, L. \& Wide, M. (1979) Chorionic gonadotrophin in the mouse from implantation to term. J. Reprod. Fert. 57, 5-9.

Zander, J. \& von Münstermann, A.M. (1956) Progesteron in menschlichem Blut und Geweben. III. Progesteron in der Placenta, in der Uterusschleimhaut und in Fruchtwasser. Klin. Wchschr. 34, 944-953.

Received 3 April 1984 